INTERNATIONAL JOURNAL OF
ORGANIZATIONAL LEADERSHIP
ORGANIIATIONAL
INADESSHIP

\title{
Conceptual Fundamentals of Organizational and Economic Mechanism Formation of Economic Sustainability Management of a Telecommunication Enterprise
}

\author{
Svitlana Birbirenko ${ }^{1 *}$, Svitlana Yevtukhova ${ }^{2}$, Marharyta Chepeliuk $^{3}$, Tetiana \\ Kravchenko $^{4}$, Liudmyla Melnyk ${ }^{5}$
}

\begin{abstract}
${ }^{1}$ Department of Enterprise Economics and Corporate Management, State University of Intellectual Technologies and
Communications, Odessa, Ukraine
\end{abstract}

${ }^{2}$ Faculty of Business and Law, Department of Economics, Management and Administration, Kherson State University, Kherson, Ukraine

${ }^{3}$ Faculty of International Relations and Journalism, Department of International economic relations, Simon Kuznets Kharkiv National University of Economic, Kharkiv, Ukraine

${ }^{4}$ Faculty of Economics, Department of business economics, Taras Shevchenko National University of Kyiv, Ukraine

${ }^{5}$ Department of Economic Disciplines, Separate Structural Subdivision College Arts and Design of Kyiv, National University of Technology and Design, Kyiv, Ukraine

\section{Keywords: \\ Economic stability, \\ Organizational and economic \\ mechanism, Management, \\ telecommunications \\ Company, COVID-19}

\section{Received}

14 July 2021

Received in revised form

12 August 2021

Accepted

12 August 2021

*Correspondence:

portalnauka2021@ukr.net

\begin{abstract}
Modern telecommunications companies operate in conditions of risk and uncertainty due to both external and internal factors. Due to the influence of various factors, companies may find themselves in a state of crisis due to the lack of a management mechanism, the main purpose of which is to ensure economic stability and efficiency based on sustainable capacity building. This article aims to identify the factors that affect the economic stability of telecommunications enterprises in Ukraine and study their impact on the integrated indicator to form an organizational and economic mechanism for managing economic stability. The study was carried out using the following methods: analysis, synthesis, generalization, systematization, correlation, and regression analysis. The main tendencies of Ukrainian telecommunication networks development are defined in this research. The key structural element of this mechanism is proposed to determine the assessment of economic stability based on the use of a set of balanced indicators. Based on correlation and regression analysis, a significant dependence of the overall integrated indicator of economic stability on the subscriber component, moderate - on the component of internal business processes and staff training and development, and a weak inverse dependence on the financial component. Using multicollinearity proved expediency to check the tightness of the relationship between the analyzed variables in the regression model.
\end{abstract}


The modern telecommunications industry of the world is moving in a new direction, which is associated with the development of $5 \mathrm{G}$ technologies, changing consumer behavior due to the COVID-19 pandemic, increasing data consumption, and increasing the volume of services provided over networks.

The economic stability of the telecommunications enterprise is objectively characterized as the basis for providing promising opportunities for its stable operation and effective development. The telecommunications sector has undergone the most drastic changes in terms of market liberalization and, according to Torres and Bachiller (2013), has dominated privatization processes in most countries, including Ukraine. The economic stability of the telecommunications company becomes especially important for countries with economies in transition, for which the presence of recessive and stagnant processes caused by the crisis through COVID-19, is particularly acute. That is why ensuring economic stability is seen as a key guideline for achieving the best results for telecommunications companies. The expediency and advantages of such a direction of the management system are due to the fact that in the presence of the proper level of economic stability, stable development of the telecommunication enterprise is carried out. However, changing economic conditions, the lack of a mechanism to respond to the global crisis caused by the pandemic, the inability to clearly predict the situation have led to the lack of an effective mechanism for managing economic stability.

All mentioned above determine the fundamental specifics of managing the economic stability of a telecommunications company. The data obtained during the evaluation will contribute to the fullest possible compliance with the particularly important principles of management interaction. It is possible to carry out this assessment with the help of a set of balanced indicators. Thus, there is a need to develop conceptual foundations for the formation of organizational and economic mechanism for managing the economic stability of the telecommunications enterprise based on a comprehensive assessment of its level.

\section{Literature Review}

The category of "sustainability" is the object of close attention of many researchers in various fields due to the need to study the functioning of complex systems and their elements. At the micro-level, the methodology of studying the economic sustainability of enterprises as open systems is now studied in the context of sustainable development (Abdulkadyrova et al., 2019; Juettner et al., 2020).

Piletska (2014) believes that the economic stability of the enterprise is a form of equilibrium, as a result of which in the conditions of external negative factors, its properties of functionality (integrity) are manifested, allowing to adapt to destabilizing factors by the complex formation and use of potential in each element of the system, to carry out evolutionary development, to keep competitive advantages for the purpose of satisfaction of public and social needs both to collective of the given enterprise, and a society as a whole. Otlyvanska (2017) and Kryvovyazyuk et al. (2021) note that the main and primary condition for ensuring the stable development of a modern enterprise is the intensification of its investment activities with the implementation of appropriate strategies, the effectiveness of which is determined by the prospects for their development and sustainability in the external environment. 
Siegrist et al. (2019) and Gaspar (2014) believe that the economic rationale for stability can be based on reducing costs, increasing revenues, and managing risks and intangible assets. In turn, Faber et al. (2005) believe that there is some confusion regarding the definition of the essence of economic sustainability, which hinders the study of the conceptual framework for its implementation. Schaltegger et al. (2016) found that the current approach to sustainable development is not efficient enough to produce the required radical transformation of enterprises, industries, and societies toward true, essential, or sustainable development.

The economic stability of the enterprise determines its further development and is ensured by the interaction of internal components of the system. Namely: financial stability ensures a state of equilibrium and immutability of the system; economic stability preserves the value of indicators, ensures the viability of the enterprise; financial stability determines the effective formation, distribution, and formation of financial resources. In determining the level of economic stability, it should be borne in mind that stability is ensured through financial and economic stability. As ensuring the economic stability of enterprises is a multi-level and complex process, and the existing methods and approaches are quite diverse, there is no clear methodology for calculating economic stability. Therefore, each industry considers its own indicators of economic stability. In their research, Romanyshyn and Shpak (2009), Shubrovskaya (2005), Liubchenko (2010), and Dmytryev and Solohub (2007) offered to use financial, social, marketing indicators, as well as an integrated indicator of economic security for assessing economic stability.

The latest scientific studies of economic sustainability are closely related to the study of the impact of coronavirus infection COVID-19 on this category. In particular, Murray (2020) believes that economists can help fight COVID-19 and prevent future epidemics. Fetzer et al. (2020) assessed the rate of onset and causal determinants of economic anxiety as a prototype of economic sustainability. They focused on how the perception of pandemic risk factors creates so-called "economic concerns". Gern and Mösle (2020) and Birbirenko et al. (2020) draw attention to the indirect effects on the economy resulting from measures to curb pandemics or changes in consumer behavior. Carlsson-Szlezak et al. (2020) believe that business leaders should carefully review market signals between different asset classes, develop a sustainability model, review market boundaries on recession and recovery models, and investigate the history of pandemics and shocks.

Almuqren and Cristea (2021) emphasize that to assess the economic consequences of the crisis caused by the COVID-19 pandemic and the vast amount of data on telecommunications companies, efficiency studies can and should be used to find solutions in competitive and volatile markets. While studying the activities of telecommunications companies, Kien (2017) emphasizes that efficiency and profitability are the top priorities of any enterprise, so the study of the relationship between efficiency and profitability should be comprehensive and continuous to predict the prospects of the business. At the same time, Widiastuti and Widya (2020) believe that the level of efficiency and concentration in the telecommunications services market are interrelated and influence each other. Therefore, the study of the cellular industry should be carried out through the prism of an effective market structure and in conditions where the number of consumers and service providers is small.

Torres and Bachiller (2013) used the Data Envelopment Analysis (DEA) methodology to study their efficiency and capacity for comparative analysis of the largest European privatized 
state-owned telecommunications operators. This analysis model is appropriate for companies whose production process does not lead to a product before providing the service.

Scientific research on this issue includes the interpretation of economic stability as an anticrisis phenomenon, as a state of the enterprise, which it is able to "resist", despite the many external and internal fluctuations. However, in our opinion, the issues concerning the scale of these destabilization processes have not been sufficiently covered, namely the circumstances under which the fundamental foundations of the stability of not only an individual economic entity, not only an individual state but almost the whole world and the whole world economy. It should also be noted the inadequacy of modern scientific proposals to make proposals for managing the economic sustainability of telecommunications companies operating in a crisis caused by the spread of COVID-19.

The purpose of the article is to identify factors that affect the economic stability of telecommunications enterprises in Ukraine, and study their impact on the integrated indicator in order to form an organizational and economic mechanism for managing economic stability.

\section{Methods}

The largest telecommunication companies of Ukraine were selected for the research, namely: PJSC Ukrtelecom, PJSC Kyivstar, and PJSC Vodafone Ukraine. The study period of macroeconomic indicators covers 2010-2020, and of the microeconomic is 2018-2020. The sources of information for the study were data from the State Statistics Service of Ukraine (2021) and the National Commission for State Regulation of Communications and Informatization (2021).

In this study, we use the model suggested by Romanyshyn and Shpak (2009), Shubrovska (2005), Liubchenko (2010); Dmytryev and Solohub (2007) to assess economic stability using an integrated indicator of economic stability, calculated by the following formula:

$I I C S=a_{1} \cdot F I+a_{2} \cdot S I+a_{3} \cdot M I+a_{4} \cdot E S I$

where

- IICS - Integrated indicator of economic stability;

- FI - financial indicator;

- SI - social indicator;

- MI - marketing indicator;

- ESI -economic security indicator.

The assessment of the economic stability of telecommunications enterprises was carried out based on the calculation of the overall integrated indicator of economic stability (y). The following factors of the internal environment were selected as factor indicators influencing the integrated indicator of economic stability (y) in the study that are relevant to telecommunication companies:

- financial indicator (x1);

- clients indicator (x2);

- marketing indicator (x3);

- social indicator $(\mathrm{x} 4)$. 
To calculate the impact of factors on the overall integrated indicator of economic stability, correlation analysis was used using the package "Data Analysis" in MS Excel, which allowed identifying the most statistically significant factors and assessing their relationship with the performance trait (y).

To check the closeness of the relationship between the analyzed variables (x1, x2, x3, x4, and y), the presence of multicollinearity, i.e., close linear dependence or strong correlation between factor (independent) variables in the regression model was investigated. This approach was chosen because multicollinearity negatively affects the quantitative characteristics of the econometric model or makes its construction impossible.

\section{Results}

The size of the telecommunications services market in the world in 2020 was estimated at 1,677.7 billion US dollars, and according to experts, in 2021-2028, the growth rate will grow by 5,4\% (Grand View Research, 2021). Next-generation technologies, the growing number of mobile subscribers, the demand for high-speed data connectivity, and managed services are contributing to the market's growth. The global communication network is undoubtedly one of the most significant areas of continuous technological progress over the past few decades.

As for Ukraine, the volume of the telecommunications services market in 2020 is about $\$ 2.7 \mathrm{bln}$. At the same time, this is a significant figure for the country's economy, as it is $1.8 \%$ of GDP. However, it should be noted that over the past ten years, despite the growth of telecommunications services, their share in GDP fell by $2.2 \%$. This fact shows a mismatch between the pace of telecommunications development and the economy's general needs (see Figure 1).

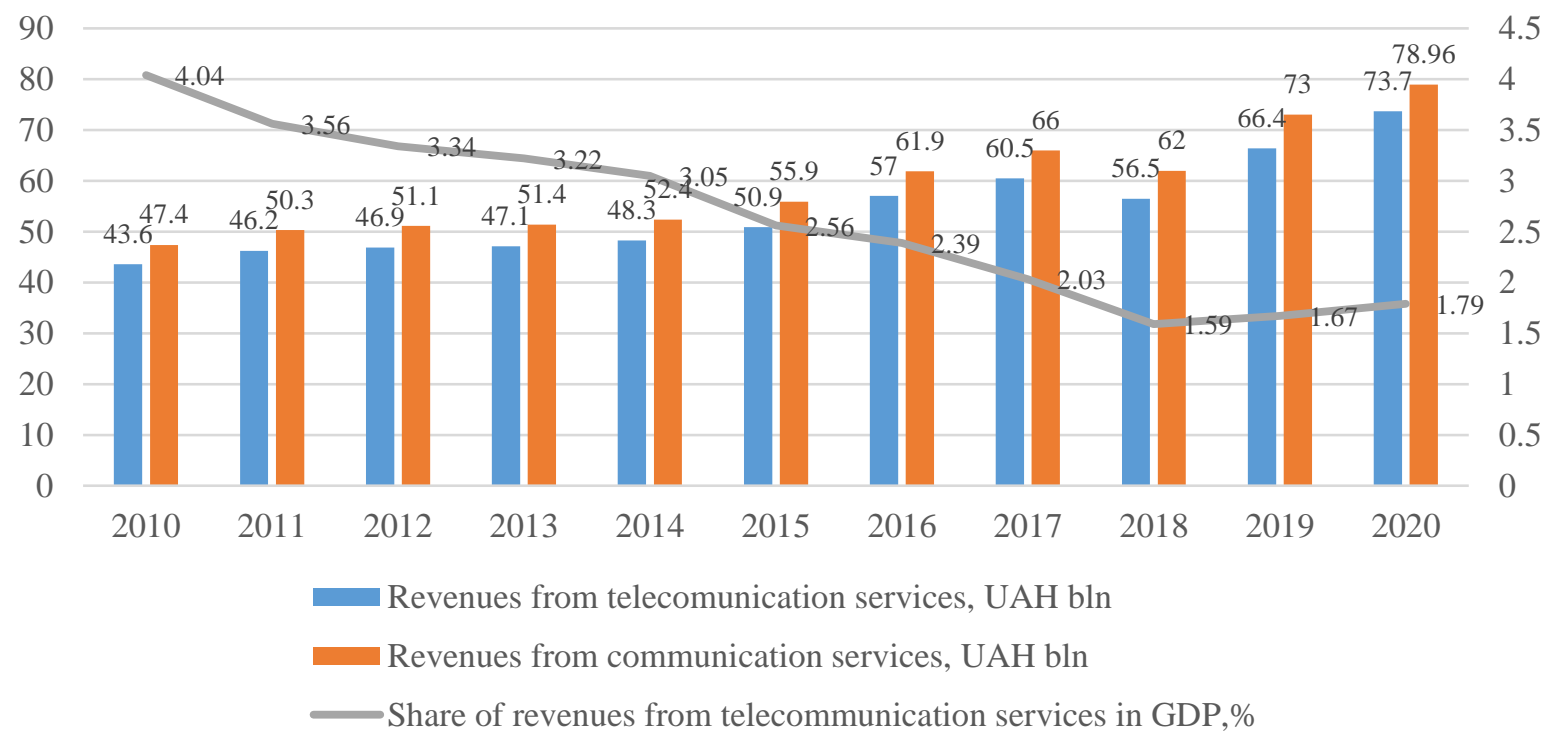

Figure 1. The size of the telecommunications services market in Ukraine in 2010-2020

In order to help telecommunications technologies meet the demands of the economy and ensure its sustainable development, it is necessary to fully implement the technology development plan provided for the coming years, according to the National Commission for State Regulation of Communications and Informatization (2021). The main elements of such a program are: 
- expansion of coverage of the territory of Ukraine by telecommunication networks of mobile (mobile) communication of the fourth generation $(4 \mathrm{G})$ with the use of radio technology "International mobile (mobile) communication IMT" in the bands of 1800 $\mathrm{MHz}$ and $2600 \mathrm{MHz}$;

- reforming and launching 4G networks in the $900 \mathrm{MHz}$ radio frequency band by mobile operators to provide modern telecommunications services in rural areas and on Ukrainian highways;

- increase in the volume of services and the number of Internet access users;

- increasing the number of users of modern electronic services, primarily in the fields of administrative services, e-commerce, medicine, education (e-Gov, e-Ticket, bank-ID, mobile-ID, GooglePay, ApplePay, e-Health, etc.);

- growing consumer demand for machine-to-machine (M2M) and Internet of Things (IoT) services, which are in demand among enterprises such as banks, security services, utilities, transport and logistics companies;

- continuation of measures to build the National Center for Operational and Technical Management of Telecommunications Networks of Ukraine to ensure the preparation and use of telecommunications networks of Ukraine in a state of emergency and martial law.

Ensuring a stable state is impossible without the participation of financially stable enterprises. Therefore, to understand the state of telecommunications companies in Ukraine, let's analyze their economic stability, using the mention above methodology with four factors of influence: finance, subscribers, marketing activity, and staff development.

Using settlement data on estimation of the specified components, the general integral indicator of economic stability of the telecommunication enterprise is calculated according to the following formula:

$\operatorname{IICS}($ tel $)=a_{1} \cdot F I+a_{2} \cdot C I+a_{3} \cdot M I+a_{4} \cdot S I$

where

- IICS (tel) - Integrated indicator of economic stability;

- FI-financial indicator;

- CI - clients`indicator;

- MI - marketing indicator;

- SI - social indicator.

Statistical estimates to determine the accuracy of the selection of the regression model allowed calculating the values of the free term and the regression coefficients of the performance indicators of each component of the complex of balanced performance of telecommunications enterprises. The results of the assessment of the economic stability of leading Ukrainian telecommunications companies are presented in Table 1. 
Table 1

Comprehensive Assessment of The Economic Stability of Ukrainian Telecommunications Companies

\begin{tabular}{|l|c|c|c|c|c|c|c|c|c|}
\hline \multirow{2}{*}{ Indicator } & \multicolumn{3}{|c|}{ PJSC Ukrtelecom } & \multicolumn{3}{c|}{ PJSC Kyivstar } & \multicolumn{3}{c|}{ PJSC "Vodafone Ukraine" } \\
\cline { 2 - 10 } & 2018 & 2019 & 2020 & 2018 & 2019 & 2020 & 2018 & 2019 & 2020 \\
\hline $\begin{array}{l}\text { Financial } \\
\text { indicator (x1) }\end{array}$ & .47 & .46 & .47 & .61 & .56 & .59 & .38 & .41 & .44 \\
\hline $\begin{array}{l}\text { Clients' } \\
\text { indicator (x2) }\end{array}$ & .49 & .47 & .45 & .67 & .68 & .66 & .64 & .59 & .52 \\
\hline $\begin{array}{l}\text { Marketing } \\
\text { indicator (x3) }\end{array}$ & .33 & .31 & .32 & .58 & .57 & .51 & .57 & .43 & .49 \\
\hline $\begin{array}{l}\text { Social indicator } \\
\text { (x4) }\end{array}$ & .51 & .48 & .52 & .75 & .69 & .71 & .59 & .66 & .71 \\
\hline $\begin{array}{l}\text { Integrated } \\
\text { indicator } \\
\text { economic } \\
\text { stability (y) }\end{array}$ & .50 & .48 & .44 & .68 & .67 & .64 & .61 & .65 & .63 \\
\hline
\end{tabular}

While conducting correlation-regression analysis, it is important to test the model for the phenomenon of multicollinearity. For the research, we use the data of PJSC "Ukrtelecom", given in Table 1, to construct a correlation matrix, which is used to measure the closeness of the relationship between the selected factor values and the performance indicator (Table 2).

Table 2

Matrix of Paired Correlation Coefficients

\begin{tabular}{|l|c|c|c|c|c|}
\hline & in & $\mathrm{x} 1$ & $\mathrm{x} 2$ & $\mathrm{x} 3$ & $\mathrm{x} 4$ \\
\hline in & 1 & -.14 & .94 & .40 & .53 \\
\hline $\mathrm{x} 1$ & -.14 & 1 & .18 & .84 & .90 \\
\hline $\mathrm{x} 2$ & .94 & .18 & 1 & .67 & -.23 \\
\hline $\mathrm{x} 3$ & .40 & .84 & .67 & 1 & .55 \\
\hline $\mathrm{x} 4$ & .53 & .90 & -.23 & .55 & 1 \\
\hline
\end{tabular}

The calculation of the matrix of paired correlation coefficients allows us to conclude that there is a significant relationship between the performance indicator (y) and the factor value $\mathrm{x} 2$ (client indicator), moderate dependence on $\mathrm{x} 3$ (marketing indicator), $\mathrm{x} 4$ (social indicator) and weak inverse relationship (-.14) with the value of $\mathrm{x} 1$ (financial indicator).

Let us note that the test for the presence of the multicollinearity phenomenon is possible to determine the dependence of factor values and necessitates the exclusion of some factors from the economic-mathematical model. According to Chaddock's scale (1925), this exception applies to factors where the relationship between the values of the absolute value of the correlation coefficients is less than .7. In our model, such an exception should be applied to the factor values $\mathrm{x} 1$ (financial indicator), which has a very strong relationship between the factor values, namely the relationship between $\mathrm{x} 1$ and $\mathrm{x} 3$ is .84 , the relationship between $\mathrm{x} 2$ (clients indicator) and $\mathrm{x} 4$ (social indicator) is .90 .

Considering the study results, we construct a correlation-regression matrix based on only two variables $\mathrm{x} 2$ and $\mathrm{x} 4$, since their correlation coefficient is greater than .5. In this case, the regression equation will look like:

$y=0.275+1.14 \times 2-0.66 \times 4$ 
Thus, the stability of telecommunications companies is determined primarily by the number of customers and staff work of companies. These factors are vital in developing a strategy for the development of telecommunications companies. Such a strategy is implemented in three stages: design, implementation, and reflection. Conceptual bases of formation are represented in Figure 2.

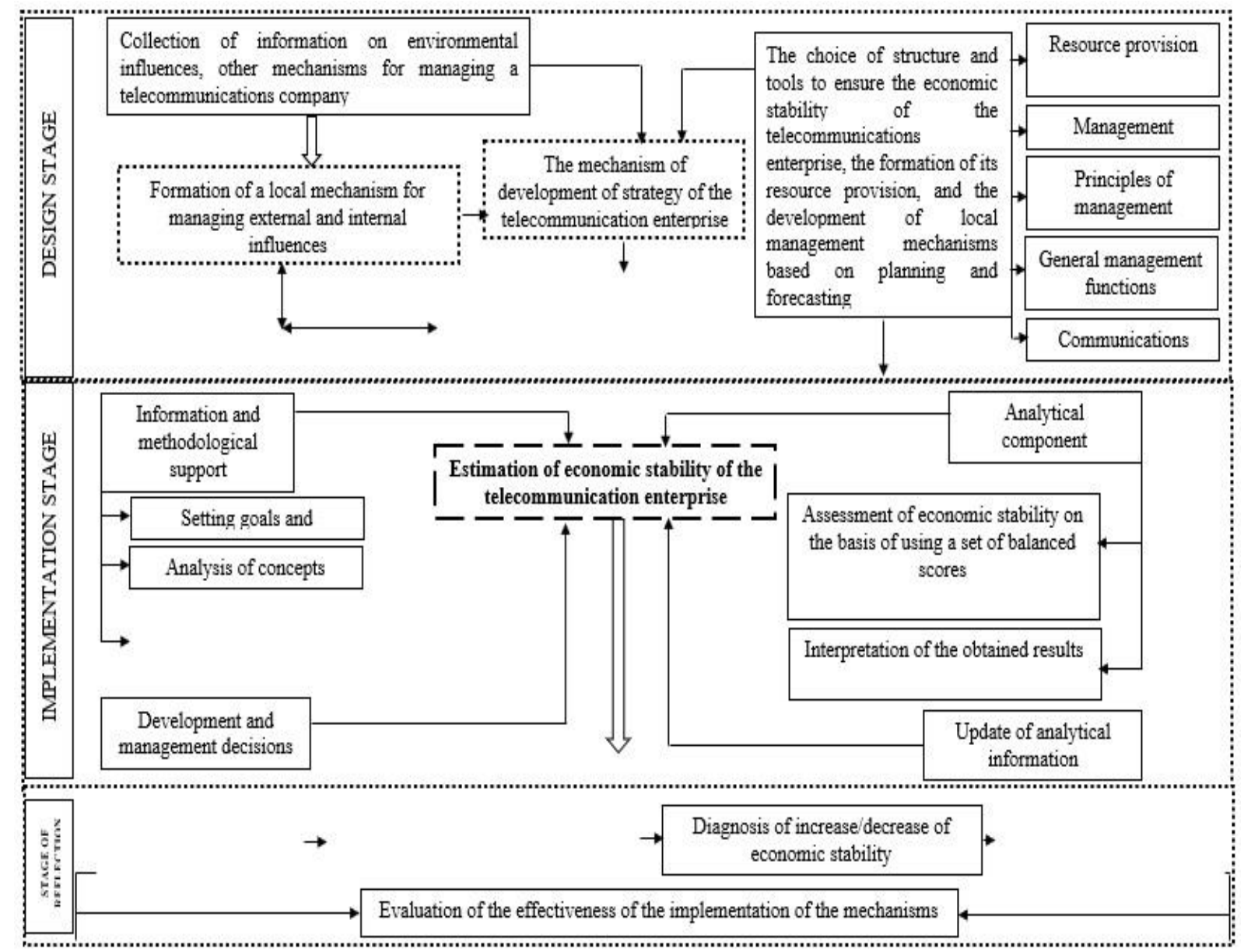

Figure 2. Organizational and economic mechanism for managing the economic stability of the telecommunications enterprise

The design stage is characterized by collecting information (mainly about the effects of the external environment), the choice of tools to ensure economic stability, the main purpose of which is based on certain principles and methods. The basic principles usually include systematization, purposefulness, hierarchy, competence, adaptability, and feedback.

At the stage of implementation, information-analytical blocks are formed, the main purpose of which is to assess the economic stability of the enterprise. Evaluation is based on the use of a set of balanced scores. No less important element of this stage is the implementation of the mechanism for forecasting the economic stability of the telecommunications company. It is based on the received data of the specified mechanisms that development and acceptance of administrative decisions concerning adjustment (if necessary) of the chosen strategy of development is carried out. This adjustment is made based on monitoring changes in the economic stability of the telecommunications company, which operates in conditions of risk and uncertainty. 
At the stage of reflection is determined the level of economic stability of the telecommunications company. A system of a number of indicators is also being formed, with the help of which it is possible to state a decrease in the level of economic stability, which is subject to a certain diagnosis. Of course, all stages are subject to control, which will ultimately determine and assess the effectiveness of the mechanisms involved.

\section{Discussion}

Among the most important areas of telecommunications services in the study from Deloitte (2021), the greatest attention is focused on sustainable development and customer needs. Almuqren and Cristea (2021) refer to external factors that affect the efficiency of telecommunications companies, such as customer satisfaction based on Sentiment Analysis. In this study, we did not take into account the factors that characterize the level of market development and market concentration in the field of cellular telecommunications. At the same time, we agree with Widiastuti and Widya's (2020) conclusions. They believe that the variables used in the calculation of economic sustainability and efficiency include income from fixed communication services and income from non-fixed communication services. The analysis method used by us correlates with the method proposed in the Suhartoko's (2020) study to determine the efficiency of telecommunications companies in East and Southeast Asia. At the same time, we propose using multicollinearity to check the closeness of the relationship between the analyzed variables in the regression model.

Torres and Bachiller (2013) argue that factors such as privatization, government regulation, and organizational change need to be considered in a study of telecommunications companies to determine their effectiveness. In a study of European telecom operators, the authors conclude that not all companies have been able to adapt equally to a competitive market. Inefficient companies have traditionally operated in the protectionist market, and they continue to be in a monopoly despite market liberalization. At the same time, the assessment of the economic sustainability of a telecommunications company is a defining component of the organizational and economic mechanism of economic sustainability management, the conceptual framework of which is proposed in this study. Formation of the mechanism of management of economic stability of the telecommunication enterprises can cover three stages: design, implementation, and reflection. Thus, all stages of management of economic stability of the telecommunication enterprise allow adapting operatively to changing conditions of the external environment and are focused on continuous reception of profit with a possibility of its increase in the end.

\section{Conclusion}

The economic environment in which the Ukrainian telecommunications company operates is characterized by uncertainty, and the negative trends have intensified against the background of the spread of coronavirus infection COVID-19. As a result, the issues of formation, preservation, and increase of economic stability based on an effective organizational and economic mechanism for managing the economic stability of the enterprise in conditions of risk and uncertainty become important. Among the other sectors of Ukraine's economy, communications and informatization have suffered the least from the pandemic, as the population has continued to use communications. 
According the results of our research, the development of telecommunications in Ukraine is growing at an ever-increasing pace. However, this pace cannot fully meet the needs of the real economy. The problem is especially acute during a pandemic when most existing businesses switch to telecommunications and digital technologies. To ensure the sustainable development of the economy, telecommunications companies must also have a stable financial and economic system.

The study proposes an integrated indicator of economic stability for telecommunications companies. It is defined as a function of the sum of indicators of financial, social, marketing, and client indicators. In correlation-regression analysis, the most important for telecommunications companies is the number of customers and skilled staff. The formula for determining the integrated indicator of economic stability, which depends on these important factors, is calculated. But to build an effective, sustainable development strategy, telecommunication companies need to go through three important stages: design, implementation, and reflection, which have specific characteristics.

All this affected the economic sustainability of telecommunications enterprises and necessitated the development of strategic aspects of its recovery. The developed theoretical and methodological principles of strategic management of economic stability of telecommunications enterprises are of a recommendatory nature, but their implementation in the practice of telecommunications operators will increase the efficiency of the telecommunications enterprise, which operates in modern market conditions.

Prospects for further research are the development of methods and practical recommendations for forecasting the economic stability of the telecommunications company, taking into account the consumer interests of users.

\section{References}

Abdulkadyrova, M., Betilgiriev, M., Israilova, Ya., Israilov, M., \& Tibilova, A. (2019). Economic sustainability as an element of the company efficiency mechanism. Proceedings of the Conference SCTCMG 2019 - Social and Cultural Transformations in the Context of Modern Globalism. https://doi.org/10.15405/epsbs.2019.12.04.186

Almuqren, L., \& Cristea, A. I. (2021). COVID-19's Impact on the telecommunications companies. Trends and applications in information systems and technologies. Proceedings of the WorldCIST 2021. Advances in Intelligent Systems and Computing, 1368. Springer, Cham. https://doi.org/10.1007/978-3-030-72654-6_31

Birbirenko, S., Zhadanova, Y., \& Banket, N. (2020). Influence of pandemic of coronavirus infection COVID-19 on economic resilience of Ukrainian enterprises. Economic Journal-XXI, 183(5-6), 66-78. https://doi.org/10.21003/ea.V183-07

Carlsson-Szlezak, P., Reeves, M., \& Swartz, P. (2020). What coronavirus could mean for the global economy. Harvard Bisiness Review. https://hbr.org/2020/03/what-coronavirus-could-mean-for-the-global-economy.

Chaddock, R. E. (1925). Principles and methods of statistics (1st Edition). Cambridge: Houghton Miffin Company,The Riverside Press.

Deloitte (2021). 2021 outlook for the US telecommunications, media and entertainment industry. https://www2.deloitte.com/us/en/pages/technology-media-and-telecommunications/articles/media-and-entertainmentindustry-outlook-trends.html

Dmytryev, Y., \& Solohub A. (2007). Estimation of economic stability of the enterprise. Visnuk Nats. tekhn. un-tu Kharkivs'kyj politekhnichnyj instytut, 7, 20-29.

Faber, N., Jorna, R., \& Engelen, J. V. (2005). The sustainability of "sustainability" - a study into the conceptual foundations of the notion of "sustainability". Journal of Environmental Assessment Policy and Management, 7(1), 1-33. 
Fetzer, T., Hensel, L., Hermle, J., \& Roth C. (2020) Coronavirus perceptions and economic anxiety. Review of Economics and Statistics, 1-36. https://doi.org/10.1162/rest_a_00946

Gaspar, J. (2014). Economic growth and multiple equilibria: A critical note. Economic Modelling, 36, 157-160.

Gern, K. J., \& Mösle, S. (2020). The impact of the COVID-19 pandemic on the global economy: Survey-based evidence from free zones. Kiel Policy Brief, 139, Kiel Institute for the World Economy (IfW), Kiel.

Grand View Research (2021). Telecom Services Market Report. https://www.grandviewresearch.com/industryanalysis/global-telecom-services-market

Juettner, U., Windler, K., Podleisek, A., Gander, M., \& Meldau, S. (2020), Implementing supplier management strategies for supply chain sustainability risks in multinational companies. The TQM Journal, 32(5), 923-938. https://doi.org/10.1108/TQM-05-2019-0136.

Kien, P. X. (2017) Researching the relationship between operational efficiency with profitability of telecommunication technology joint-stock companies, VNU Journal of Science: Economics and Business, 33(2), https://doi.org/10.25073/2588-1108/vnueab.4069.

Kryvovyazyuk, I, Otlyvanska, G, Shostak, L., Sak, T., Yushchyshyna, L., Volynets, I., \& Visyna, T. (2021). Business diagnostics as a universal tool for study of state and determination of corporations development directions and strategies, Strategies Academy of Strategic Management Journal, 2(20), 1-14.

Liubchenko, N. (2010). Mechanism to ensure the sustainability of industrial enterprises [Unpublished doctoral dissertation). Khmelnytskyj, Ukraine.

Murray, E.J. (2020). Epidemiology's time of need: COVID-19 calls for epidemic-related economics. Journal of Economic Perspectives, 34 (4), 105-120. https://doi.org/10.1257/jep.34.4.105.

National Commission for State Regulation of Communications and Informatization (2021). The official web portal. https://nkrzi.gov.ua

Otlyvanska, G. A. (2017). Investment activity of telecommunications providers: conditions, problems, and trends. Naukovyj visnyk Polissia, 2(10), 113-119. https://doi.org/10.25140/2410-9576-2017-1-2(10)-113-119

Piletska S. T. (2014) The essence of economic stability and its relationship with crisis processes in the enterprise. Business Inform, 5, 286-290.

Romanyshyn, M., \& Shpak, N. (2009). The economic stability of the enterprise: the nature and its components. Naukovyj visnyk Natsionalnoho lisotekhnichnoho universytetu Ukrainy, 19(10), 248-253

Schaltegger, S., Lüdeke-Freund, F., \& Hansen E. G. (2016). Business models for sustainability: a co-evolutionary analysis of sustainable entrepreneurship, innovation, and transformation. Strategic Organization, 12(1), 70-78.

Shubrovska, O. (2005). Sustainable economic development: concept and direction of research. Ekonomika Ukrainy, 1, 3642 .

Siegrist, M., Bowman, G., Mervine, E., \& Southam, C. (2019). Embedding environment and sustainability into corporate financial decision-making. Accounting and Finance, 60(1), 129-147. https://doi.org/10.1111/acfi.12533

State Statistics Service of Ukraine (2021). Official site. http://www.ukrstat.gov.ua/

Suhartoko, P. M. S. (2020). Analysis of efficiency in telecommunication technology companies in Eastern and South East Asia using analysis data envelopment method, in Digital Economy for Customer Benefit and Business Fairness. Proceedings of the International Conference on Sustainable Collaboration in Business, Information and Innovation (SCBTII 2019), Bandung, Indonesia, October 9-10, 2019, Routledge.

Torres, L., Bachiller, P. (2013). Efficiency of telecommunications companies in European countries. Journal of Management and Governance, 17, 863-886 (2013). https://doi.org/10.1007/s10997-011-9203-4

Widiastuti, N., \& Widya S. (2020) Technical Efficiency on the Operator Industry of Telecommunication in Indonesia. Palarch's Journal of Archaeology of Egyptology, 17(3), 12-24. 


\section{Acknowledgements}

Not applicable.

\section{Disclosure Statement}

No potential conflict of interest was reported by the authors.

\section{Funding Acknowledgements}

Not applicable.

\section{Open Access}

The International Journal of Organizational Leadership publishes open access articles under the terms of the Creative Commons Attribution (CC BY) License, which permits use, distribution, and reproduction in any medium, provided the original work is properly cited. 